\title{
$\mathrm{FRP}$ 작품 보존을 위한 자외선 열화 특성 및 자외선 차단 코팅제 적용 연구
}

한예빈 | 정용재 ${ }^{1}$

한국전통문화대학교 문화유산전문대학원 문화재수리기술학과

\section{UV Degradation Characteristics and Applicability of Coating Agent for Conservation of FRP Artifacts}

\author{
Ye Bin Han I Yong Jae Chung ${ }^{1}$ \\ Department of Cultural Heritage Conservation \& Restoration, Graduate School of Cultural Heritage, \\ Korea National University of Cultural Heritage, Buyeo, 33115, Korea \\ ${ }^{1}$ Corresponding Author: iamchung@nuch.ac.kr, +82-41-830-7365
}

\begin{abstract}
초 록 본 연구에서는 야외 플라스틱 작품에 많이 사용되고 있는 유리섬유강화플라스틱(FRP)을 대상으로 자외선에 의한 색도 및 광택도, 접촉각 변화, 적외선 분광분석을 통해 열화 특성을 확인하였으며, $\mathrm{FRP}$ 의 열화를 예방하고자 자외선 차단 코팅제를 제조하여 코팅제의 성능 평가를 진행하였다. 자외선 열화 결과, FRP의 표면변화는 기공 이외에 다른 변화는 관찰되지 않았다. 색차는 열화 초기에 급격히 증가하였는데 이는 적외선 분광분석 결과와도 유사하였다. 광택도 및 접촉각의 경우 뚜렷한 변화는 확인되지 않았다. 코팅제 처리에 따른 특정한 표면 변화는 관찰되지 않았으나 색차 비교 결과, 미처리 시편보다 색 변화가 낮게 측정되어 변색 제어가 가능함을 확인하였다. 코팅제 도포 후 열화에 따른 광택도 및 접촉각 변화가 일부 관찰되었으나 자외선 차단 코팅제는 상대적으로 안정한 것으로 나타났다. 적외선 분광분 석 결과, 화학적 변화가 미미함에 따라 코팅제가 일정 기간 동안 열화를 지연시키는 것으로 보인다. 본 연구를 통해 작품 재료로써 FRP의 자외선 열화 양상을 파악하였으며, 제조한 자외선 차단 코팅제의 성능 평가를 통해 야외 FRP 작품의 보존 방안으로써 적용 가능성을 확인하였다.
\end{abstract}

\section{중심어: FRP 작품, 자외선 열화, 자외선 안정제, 코팅, 예방보존}

ABSTRACT This study evaluated the degradation characteristics of FRP by ultraviolet (UV) rays and applied a UV-resistant coating to prevent the degradation of the surface of these sculptures. As a result of the degradation caused by UV rays, there were slight changes in the FRP surface and contact angle. The chromaticity sharply increased in the early phase of degradation. After applying the coating to the FRP, no significant surface changes were observed. However, it had lower changes in color as compared to the uncoated specimen, so it was verified that the control of discoloration could be possible. Some changes in the gloss and contact angle were observed depending on the extent of degradation, but the UV coating agent remained relatively stable. Analysis of the infrared light spectrum showed that there were almost no chemical changes, and it could be concluded that the coating treatment prevented degradation for a certain period. This study investigated the degradation of FRP used as materials in artwork exposed to UV rays, and it was found that there was a delay in the onset of degradation in the FRP with the UV-resistant coating when compared to the uncoated FRP.

Key Words: FRP artworks, UV degradation, UV stabilizer, Coating, Preventive preservation 


\section{1. 서 론}

회화, 조각품 등 예술작품은 미술관, 박물관과 같은 실 내 공간에서 전시되어왔으며, 근대 이후부터 재료 및 기법 의 발전, 사회적 인식 변화 등으로 제한된 공간을 벗어나 야외로 확장되었다. 야외 작품의 재료는 돌, 나무, 흙에서 점차 금속, 유리, 합금 등으로 발전하였으며(Park, 2016), 최근에는 알루미늄, 플라스틱, 복합재료 등 다양한 재질로 구성되고 있다. 그 중 플라스틱은 기존의 재료보다 가볍고 작가의 의도대로 제작이 가능하며, 내구성이 우수한 것으 로 알려져 최근에는 공공 예술영역에서 대형 또는 야외 작 품의 재료로 사용되고 있다. 그러나 야외 플라스틱 작품은 자외선, 온도, 수분 등 외부환경에 직접적으로 노출되면서 기존의 인식과는 달리 균열, 박락, 변색 등 열화가 발생하 였다. 플라스틱의 취약성을 보완하고 성능을 개선하고자 플라스틱 제작 과정 중 자외선 안정제, 산화 방지제 등의 첨가제가 사용되나(Jeon et al., 2013), 시간 경과에 따른 물 리적, 화학적 열화는 피할 수 없는 부분이다.

플라스틱 보존에 관한 연구는 1966년 영국을 시작으로 발전하였으며, 국내에서는 2010년부터 플라스틱의 동정방 법 및 열화양상 평가 등이 진행되었다(Chung et al., 2013; $\mathrm{Yu}, 2013)$. 야외 플라스틱 작품에 관한 연구는 2012년부터 $\mathrm{GCI}(\mathrm{Getty}$ Conservation Institute)를 중심으로 발표되기 시 작하여 넓은 범위에서 야외 도장 작품(Outdoor Painted Sculptures)에 대한 연구가 진행되었으며, 그 중 플라스틱 작품은 보존처리 사례를 통해 작품의 구조적 보강, 표면 페 인트 층의 보수 및 재처리 방법 등이 언급되었다(Getty Conservation Institute, 2012). 또한 일부 연구를 통해 야외 플라스틱 작품의 예방보존을 위한 방안으로 주기적인 클리 닝과 코팅방법 등이 제시되었으나(Breder, 2013), 야외 플 라스틱 작품의 열화특성, 보존처리 및 관리방안 등에 대한 연구는 시작 단계라 할 수 있다.

야외 플라스틱 작품은 다양한 재료 중 유리섬유강화플 라스틱(FRP, Fiberglass Reinforced Plastics)이 주로 사용되 고 있다. FRP는 불포화폴리에스테르 수지에 유리섬유를 적층하여 경화시킨 것으로 내구성 및 강도가 우수하며, 상 온·저압의 조건에서 성형이 자유롭다는 장점을 가진다. 이로 인해 FRP는 1940년대 이후 현대 예술작품의 재료로 등장하였으며, 최근까지도 다양한 작품에 사용되고 있다 (Lee, 2006). FRP에 관한 연구는 미술 분야에서 작품의 디 자인적 요소나 미술사의 일부로 언급되었을 뿐(Shin, 2005;
Youn et al., 2011), 대부분 산업 분야에서 건축물, 기계공학 의 재료로써 재료 특성 및 구조적 변형 등에 관한 물성평가, 개선 연구 등이 수행되었다. 특히 자외선에 의한 재료의 표 면변화, 접촉각 측정, 표면 전위나 저항률 변화 등 표면 열 화 위주로 연구되었다(Lee et al., 1996; Lee and Lee, 1999). 플라스틱과 같은 고분자는 안정한 물질로 여겨지나, 일반 적으로 열이나 빛, 산소 등 외부 환경요인으로 인한 열화가 발생한다. 그 중 자외선은 광량은 적으나 에너지가 높아 유 기물 내 주요 결합이 활성화되면서 연속적인 분해가 발생 되므로(Nam et al., 2006), 이로 인한 열화 원인 규명 및 제 어를 위한 연구가 다수 진행된 것으로 보인다. 그러나 작품 재료로써 FRP에 관한 연구는 미미한 상황이며, 고분자의 특성으로 보아 외부 환경요인에 의한 재료적 물성변화, 재 질의 열화에 따른 보존처리 방안 등이 연구될 필요가 있다.

현재까지 외부 환경에 노출된 작품의 보존 방법으로 코팅 제 관련 연구가 수행되었으며, 주로 야외 조형물 중 높은 비중 을 차지하는 금속을 대상으로 이루어졌다. 코팅제로 사용되는 아크릴계 수지 및 왁스의 물성평가, 적용성 연구 등을 통해 야 외 금속 작품에 적합한 코팅제를 평가하였으며(Park, 2006; Oh, 2010), 새로운 코팅제에 대한 연구도 진행되었다(Beom, 2012). 이러한 금속 작품의 코팅처리 방법은 야외 FRP 작품 에도 일부 적용되는 것으로 보고되어지나(Beerkens and Breder, 2012), 코팅처리에 따른 재질 안정성, 코팅효과 등에 관한 연 구는 거의 수행되지 않은 것으로 보아 야외 플라스틱 작품의 열화 방지를 위한 연구 역시 부족한 실정이다.

따라서 본 연구에서는 야외 플라스틱 작품의 바탕재료 로 사용되고 있는 FRP의 기초 열화 특성을 파악하였다. 또 한 자외선에 의한 열화를 예방하고자 자외선 차단 코팅제 를 제조하여 FRP에 도포함으로써 코팅제의 적용 가능성을 확인하였으며, 이러한 코팅처리 방법을 통해 FRP 야외 플 라스틱 작품의 예방보존 방안을 제시하고자 한다.

\section{2. 재료 및 방법}

\section{1. 실험 재료}

2.1.1. 유리섬유강회플라스틱(Fiberglass Reinforced Plastics) 유리섬유강화플라스틱(FRP)은 불포화폴리에스테르 수 지를 주재료로 하며 유리섬유, 탄소섬유 등의 함침을 통해 수지의 강도를 보강한 것을 말한다. 불포화폴리에스테르 수지는 열경화성 플라스틱의 일종으로 불포화기를 함유하 고 에스테르 결합기를 가진 고분자 화합물이다. 불활성가 
Table 1. Characteristics of unsaturated polyester resin

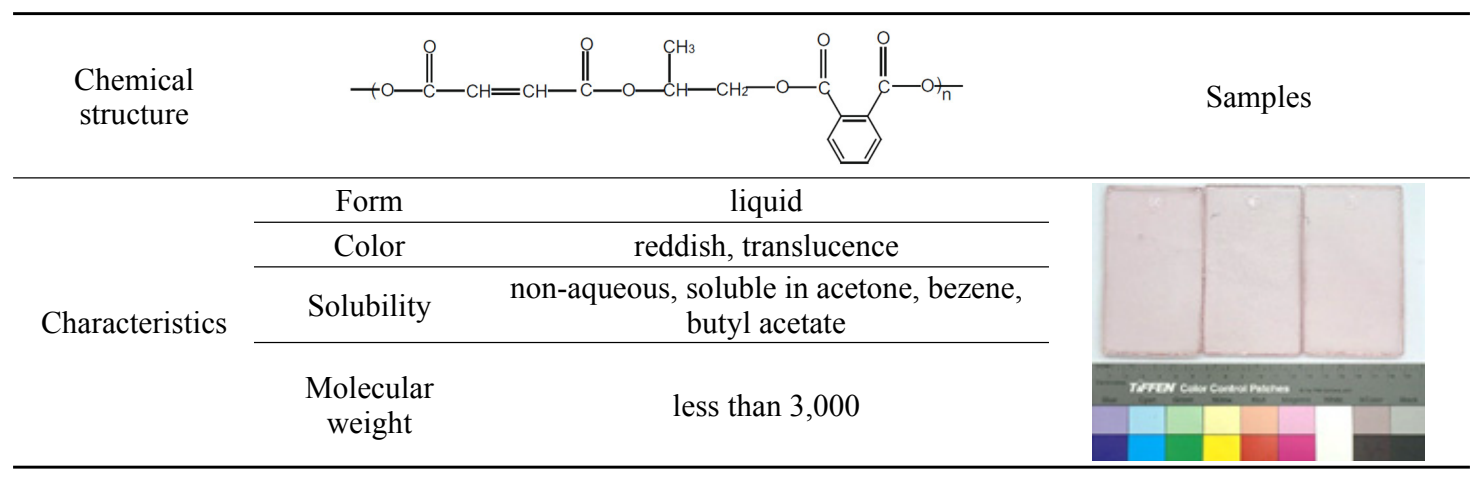

스 내에서 포화 2염기산, 불포화 2염기산의 글리콜 반응을 통해 얻은 불포화폴리에스테르 수지를 스티렌 등의 비닐 단량체에 용해시켜 생산하는데 각 원료의 배합량에 따라 그 성질은 다양하게 나타난다(Table 1). 내구성, 내충격성, 내마모성 등이 우수하고 녹슬지 않으며, 열경화성 수지이 므로 고온에서도 변형시킬 수 없다는 특징이 있다. 그러나 현재까지 FRP의 제작방법은 공인된 시방서 또는 표준화된 방법이 정립되어 있지 않으며, 동일한 FRP 작품임에도 불 구하고 작가에 따라 재료의 물성이 변하는 특성을 지닌다. 또한 일반적으로 제시되는 혼합비를 적용할 경우에도 양질 의 플라스틱이 제작되기까지 재현성이 높지 않다는 재료적 한계가 존재한다(Ha, 2013).

\subsection{2. 코팅제}

자외선 차단 코팅제를 제조하기에 앞서 문화재 분야에 서 금속, 도토기 등 유물의 강화제 및 코팅제로 주로 사용 되는 Paraloid B-72를 기본 코팅제로 선정하였는데 이는 액 상으로 첨가물과 혼합이 용이함에 따라 적용하였다. 기존 의 코팅제에 자외선 차단 효과를 부여하기 위해 자외선 안 정제를 사용하였다. 자외선 안정제는 고분자 첨가제로써 자외선으로부터 플라스틱이 분해되거나 변색 또는 물성이 약화되는 것을 억제하며, 작용기에 따라 자외선 흡수제 (UV Absorber), Hindered Amin Light Stabilizer(HALS), Quenchers, 과산화물 분해제(Hydroperoxide decomposer) 로 구분된다. 그 중 benzotriazole계의 자외선 흡수제와 HALS계를 사용하였다. 특히 자외선 흡수제와 HALS를 혼 합해서 사용할 경우 각각의 특성을 서로 보완하여 상승효 과를 나타내는 것으로 알려져 있다(Mun, 2003).

용매는 코팅제 및 자외선 안정제를 모두 용해시킬 수 있 는 것으로 선정하였다. 일반적으로 Paraloid B-72의 용매는
아세톤이나 톨루엔, 자일렌 등이 사용되어왔으나(Cho and Cho, 2008; Oh, 2012) 아세톤과 톨루엔의 경우 플라스틱과 같은 합성수지를 용해시킬 수 있는 문제가 있다. 본 연구에 서는 다른 유기용매보다 Paraloid B-72에 대한 용해도는 낮 으나 상대적으로 플라스틱에 안정한 에탄올 $\left(\mathrm{C}_{2} \mathrm{H}_{6} \mathrm{O}\right)$ 과 Paraloid B-72 뿐만 아니라 자외선 안정제의 용해성도 우수 한 자일렌 $\left(\mathrm{C}_{6} \mathrm{H}_{4}\left(\mathrm{CH}_{3}\right)_{2}\right)$ 을 용매로 선정하였다.

\subsection{3. 시편제작}

\section{유리섬유강화플라스틱}

모든 시편의 크기를 동일하게 제작하기 위해 일정한 크 기의 실리콘 몰드 안에 불포화폴리에스테르 수지(CH-304, AEKYUNG Chemical Co., KOR)를 부어 실험시편을 제작 하였다. FRP의 경우 일반적으로 플라스틱의 강도를 보강 하기 위하여 불포화폴리에스테르 수지에 유리섬유를 침적 시켜 사용하지만 본 실험에서는 FRP 표면과 코팅제의 관 계를 평가하고자 하였으므로 유리섬유를 제외한 불포화 폴 리에스테르 수지만을 사용하였다. 시편은 3 배수로 제작하 였으며 상온에서 24 시간 자연 경화 후 증류수를 이용해 2 회 세척한 뒤 자연 건조하였다.

\section{코팅제 도포시편}

자외선 차단 코팅제는 최적 비율 탐색에서 선별된 코팅 제를 사용하였으며, 시중에 판매되고 있는 코팅제와의 비 교를 통해 자외선 차단 코팅제의 성능을 평가하고자 비교 군으로 클리어코트(Multiplus 5400 clear, $\mathrm{KCC}, \mathrm{KOR}$ )와 바 니시(Artist gloss varnish, WINSOR\&NEWTON, GBR)를 사 용하였다. 본 실험에서 사용한 클리어 코트는 일반적으로 야외 예술작품의 표면 보호 및 광택 부여를 위해 가장 상부 층에 사용되는 투명 도료(Clearcoat)이며, 바니시는 일반적 
Table 2. Production ratio of UV-resistant coating by a single solvent

\begin{tabular}{|c|c|c|c|}
\hline $\begin{array}{l}\text { Sample } \\
\text { name }\end{array}$ & \multicolumn{2}{|c|}{$\begin{array}{l}\text { Coating solution } \\
\text { (Paraloid B-72) }\end{array}$} & $\begin{array}{l}\text { UV stabilizers } \\
\text { (BTA+HALS) }\end{array}$ \\
\hline E10-U1 & \multirow{4}{*}{ Ethyl alcohol } & \multirow{2}{*}{$10 \%$} & $1 \%$ \\
\hline E10-U2 & & & $2 \%$ \\
\hline E20-U1 & & \multirow{2}{*}{$20 \%$} & $1 \%$ \\
\hline E20-U2 & & & $2 \%$ \\
\hline X10-U1 & \multirow{2}{*}{ Xylene } & \multirow{2}{*}{$10 \%$} & $1 \%$ \\
\hline X10-U2 & & & $2 \%$ \\
\hline
\end{tabular}

으로 유화 작품에 사용되는 코팅제이다. 바코터를 사용하 여 FRP 표면 위에 각 코팅제를 도포한 후 상온에서 12 시간 동안 눕혀서 건조하였으며, 시편별 3 배수로 제작하였다.

\section{2. 실험 방법}

\subsection{1. 자외선 차단 코팅제 제조 및 평가}

자외선 차단 코팅제는 문화재 분야에서 유물의 강화제 및 코팅제로 사용되는 Paraloid B-72를 기본 코팅제로 하였 으며, 자외선 차단 효과를 부여하기 위해 자외선 안정제를 첨가하여 다양한 비율로 조합하였다. 용해도 평가 및 자외 선-가시광선 분광분석기(Agilent $8453 \mathrm{UV}$-Visible Spectro photometer, Agilent, USA)를 통한 자외선 투과력을 비교하 여 적합한 자외선 차단 코팅제를 선정하였다.

\subsection{2. 열화 조건}

자외선에 의한 FRP의 표면 열화 특성을 평가하기 위하여 실제 안면도 지역의 자외선량(UV-A)(Korea Meteorological Administration, 2016)을 분석하여 우리나라 연평균 시간 당 자외선 조사세기는 $0.087 \mathrm{~W} / \mathrm{m}^{2}$, 조사시간은 약 13 시간 임을 확인하였다. 이를 통해 자외선 조사량 $\left(\right.$ 조사세기 $\left(\mathrm{W} / \mathrm{m}^{2}\right) \times$ 조사시간(s))을 도출한 후 QUV 촉진내후성시험기(QUV/se, $\mathrm{Q}-\mathrm{Lab}, \mathrm{USA})$ 를 사용하여 자외선 조사 6시간(UV-A 340 $\left.\mathrm{nm}, 0.35 \mathrm{~W} / \mathrm{m}^{2}, 45^{\circ} \mathrm{C}\right)$, 휴지기 3 시간(Dark, $\left.34^{\circ} \mathrm{C}\right)$ 으로 총 9 시간을 열화 1 회로 설정하였다. 열화 90 시간 마다 변화를 관찰하였으며, 열화는 총 630시간 실시하였다.

\subsection{3. 평가 방법}

자외선 열화에 따른 표면 변화를 관찰하기 위하여 광학 현미경(Eclipse Ni-U, Nikon, JPN)을 사용하여 40배율로 조사하였으며, 색도 및 광택도(A-6800, BYK, USA) 측정
Table 3. Production ratio of UV-resistant coating by mixed solvents

\begin{tabular}{|c|c|c|c|c|}
\hline Sample name & $\begin{array}{l}\text { Coating } \\
\text { (Paralo }\end{array}$ & $\begin{array}{l}\text { ution } \\
-72)\end{array}$ & $\begin{array}{r}\text { UV stab } \\
\text { solut }\end{array}$ & zers \\
\hline EX 8 & \multirow{3}{*}{$\begin{array}{l}\text { Ethyl } \\
\text { alcohol }\end{array}$} & $8 \%$ & \multirow{3}{*}{ Xylene } & \multirow{3}{*}{$1 \%$} \\
\hline EX 10 & & $10 \%$ & & \\
\hline EX 12 & & $12 \%$ & & \\
\hline Solvent ratio & 4 & 1 & & \\
\hline
\end{tabular}

을 통해 열화 전, 후의 색상 변화를 확인하였다. 표면접촉 각측정기(GH11, KRUSS, GER)를 사용하여 접촉각 변화를 비교하였으며, 적외선 분광분석(Alpha, BRUKER, GER)을 통해 열화에 의한 고분자의 화학구조 변화 및 카르보닐 지 수(Carbonyl Index)를 계산하여 열화정도를 평가하였다.

\section{3. 결 과}

\section{1. 자외선 차단 코팅제 최적 비율 탐색}

\subsection{1. 코팅제 제조}

\section{단일용매}

자외선 차단 코팅제는 다음과 같은 비율로 제조하였다. 에탄올과 자일렌을 용매로 사용하였으며, 코팅제 농도는 일반적으로 금속 유물의 코팅제 및 강화제에 적용되는 농 도 $10 \%, 20 \%$ 를 적용하였다. 에탄올을 용매로 한 코팅제의 경우 상온에서 Paraloid B-72가 용해되는 시간이 오래 소요 되어 열을 가하여 용해시켰다. 자일렌을 용매로 한 경우 용 해도는 우수하였으나 농도 $20 \%$ 인 코팅제는 점성이 매우 높아 사용하기 어려움이 있어 제외하였다. 각각의 코팅제 에 자외선 안정제 $1 \%, 2 \%$ 를 첨가하여 자외선 차단 코팅제 를 제조하였다(Table 2).

\section{혼합용매}

코팅제 Paraloid B-72와 자외선 안정제를 각각의 용매에 용 해시켜 혼합하는 방법을 사용하였다. 코팅제는 에탄올, 자외 선 안정제는 자일렌에 용해시켰다. 코팅제 용매는 농도 $10 \%$ 를 기준으로 조절하여 $8 \%, 10 \%, 12 \%$ 로 설정하였다(Table 3 ).

자외선 안정제는 $1 \%$ 로 고정하였으며, 용매는 자일렌을 사용하여 자외선 안정제가 용해되는 최소량을 파악하였다. Paraloid B-72 코팅제와 자외선 안정제 각각의 용매 비율은 $4: 1$ 이 되도록 하였으며, 자외선 안정제는 전체 용매 대비 $1 \%$ 로 제조하였다(Table 3 ). 
Table 4. Manufactured UV-resistant coating by a single solvent and mixed solvents

\begin{tabular}{lllll}
\hline & Single solvent & Mixed solvent \\
\hline $\mathrm{E} 10(\mathrm{U} 1, \mathrm{U} 2)$ & $\mathrm{E} 20(\mathrm{U} 1, \mathrm{U} 2)$ & $\mathrm{EX}(8,10,12)$ \\
\hline
\end{tabular}

3.1.2. 용해도 평가 단일용매

에탄올을 용매로 한 코팅제는 코팅제와 자외선 안정제 의 혼합 후 침전물이 발생하였다. 코팅제에 자외선 안정제 가 거의 용해되지 않았으며 자외선 안정제 농도가 높아질 수록 침전물이 증가하였다. 자일렌 용매의 경우 자외선 안 정제의 용해도가 우수하였으나 자외선 안정제 농도 $2 \%$ 에 서는 침전물이 미세하게 확인되었다.

\section{혼합용매}

자외선 안정제는 자일렌에 완전히 용해되었으며, 자외 선 안정제 용액은 에탄올을 용매로 한 Paraloid B-72 코팅 제와 이질감 없이 혼합되었다. 단일용매와는 다르게 침전 물은 발생하지 않았으나 상온에서 혼합할 경우 일부 입자 가 관찰되어 열을 가하여 용해도를 높여주었다(Table 4).

\subsection{3. 자외선 차단력 평가}

\section{단일용매}

자외선 차단력 비교 결과, 자외선 안정제를 첨가한 코팅제 는 미첨가 코팅제보다 자외선 차단에 효과적인 것으로 확인되 었다. 에탄올을 용매로 한 코팅제의 경우 자외선 안정제가 첨 가되지 않은 코팅제 E10, E20은 자외선 투과율이 $60 \%$ 이상으 로 나타난 반면 자외선 안정제 첨가 시 자외선 안정제가 거의 용해되지 않은 E10-U2를 제외한 코팅제 E10-U1, E20-U1, E20-U2에서는 자외선 투과율이 $6 \%$ 이하로 측정되었다.

자일렌을 용매로 한 코팅제 역시 자외선 안정제가 첨가 되지 않은 코팅제 X10은 약 $80 \%$ 의 자외선 투과율을 보였
으며, 자외선 안정제를 첨가한 코팅제에서는 낮은 투과율 이 확인되었다. 자외선 안정제가 $1 \%(\mathrm{X} 10-\mathrm{U} 1)$ 일 때 투과율 이 0 에 가깝게 나타났으나 $2 \%(\mathrm{X} 10-\mathrm{U} 2)$ 에서는 오히려 투 과율이 증가하였다.

혼합 용매

자외선 차단력 평가 결과, 코팅제의 농도가 $8 \%(\mathrm{EX} 8)$ 인 경우 투과력은 $15 \%$ 로 나타났으며, 농도 $10 \%(\mathrm{EX} 10)$ 는 약 $5 \%$, 농도 $12 \%(\mathrm{EX} 12)$ 는 투과력이 거의 0 에 가까운 것으로 측정되었다. 코팅제의 농도가 높을수록 투과력이 낮아 자 외선 차단에 효과적인 것으로 나타났다(Table 5).

코팅제에 적용한 용매 종류 및 제조 방법 결과, 가장 적 합한 자외선 차단 코팅제는 에탄올을 용매로 한 농도 $10 \%$, $12 \%$ 의 Paraloid B-72 코팅제와 자일렌에 용해시킨 농도 $1 \%$ 의 자외선 안정제 용액을 혼합한 $\mathrm{EX} 10, \mathrm{EX} 12$ 인 것으로 확인되었다(Table 6).

\section{2. 자외선 열화에 따른 $\mathrm{FRP}$ 의 열화 특성 및 코팅 제 성능 평가}

\subsection{1. 표면관찰}

$\mathrm{FRP}$ 의 표면관찰 결과, 열화 전과 후 눈에 띄는 표면변화 는 나타나지 않았다. 전반적으로 열화가 진행될수록 표면 에 기공 및 이물질이 증가하였으며, 주로 열화 360 시간 이 후부터 더욱 뚜렷하게 관찰되었다. 이는 플라스틱 내부에 있던 기포나 수분의 용출로 인해 발생한 것으로 보인다.

코팅제를 도포한 FRP의 열화 후 표면관찰 결과, 코팅제 
Table 5. UV transmittance spectrum of UV-resistant coating

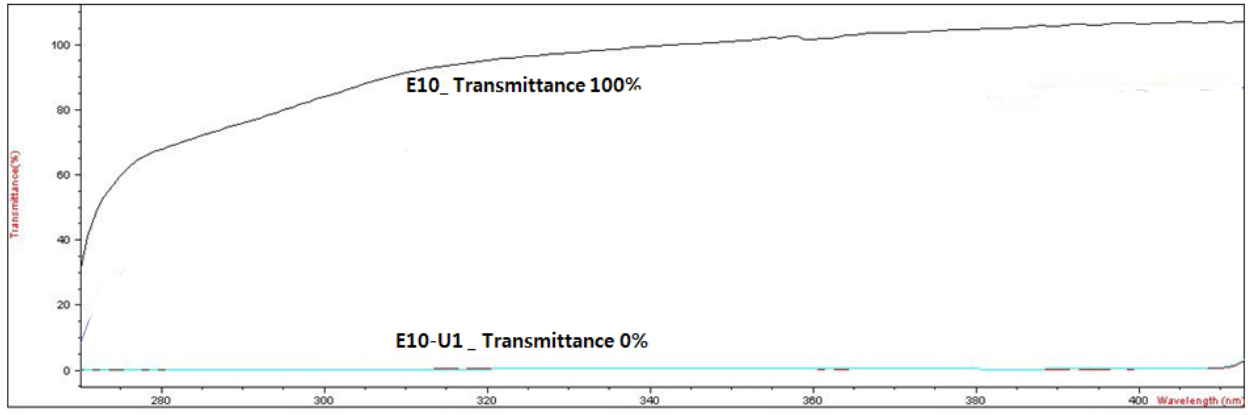

Single solvent
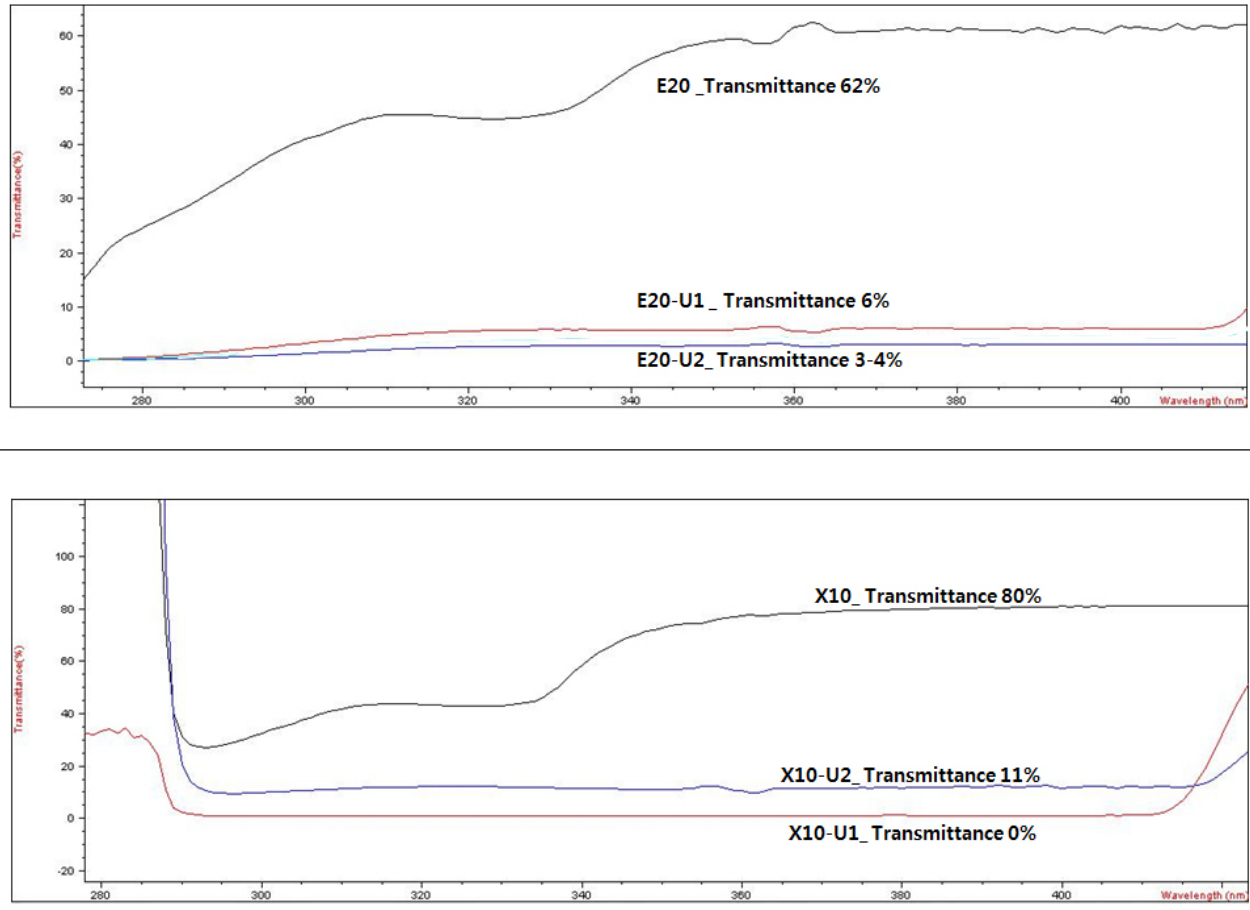

Mixed solvents

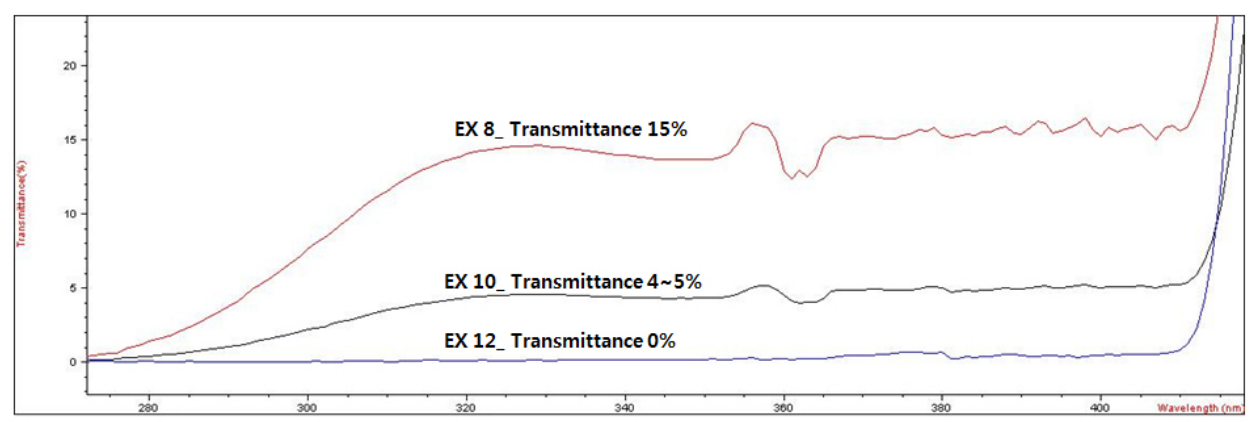


Table 6. Performance evaluation of UV-resistant coating by production method

\begin{tabular}{|c|c|c|c|c|c|c|c|}
\hline & $\begin{array}{l}\text { Sample } \\
\text { name }\end{array}$ & $\begin{array}{l}\text { Coating solution } \\
\text { (Paraloid B-72) }\end{array}$ & $\begin{array}{c}\text { UV } \\
\text { stabilizers }\end{array}$ & Solubility & $\begin{array}{c}\text { UV } \\
\text { blocking }\end{array}$ & \multicolumn{2}{|c|}{ Suitability } \\
\hline \multirow{6}{*}{$\begin{array}{l}\text { Single } \\
\text { solvent }\end{array}$} & E10-U1 & \multirow{2}{*}{$\begin{array}{c}10 \% \\
\text { in ethyl alcohol }\end{array}$} & $1 \%$ & $-*$ & ++ & \multirow{4}{*}{$\begin{array}{l}\text { low } \\
\text { solubility }\end{array}$} & \multirow{6}{*}{-} \\
\hline & E10-U2 & & $2 \%$ & - & +++ & & \\
\hline & E20-U1 & \multirow{2}{*}{$\begin{array}{c}12 \% \\
\text { in ethyl alcohol }\end{array}$} & $1 \%$ & - & ++ & & \\
\hline & E20-U2 & & $2 \%$ & - & - & & \\
\hline & X10-U1 & \multirow{2}{*}{$\begin{array}{c}10 \% \\
\text { in xylene }\end{array}$} & $1 \%$ & +++ & +++ & \multirow{2}{*}{ toxic } & \\
\hline & $\mathrm{X} 10-\mathrm{U} 2$ & & $2 \%$ & +++ & + & & \\
\hline \multirow{3}{*}{$\begin{array}{l}\text { Mixed } \\
\text { solvents }\end{array}$} & EX8 & $\begin{array}{c}8 \% \\
\text { in ethyl alcohol }\end{array}$ & \multirow{3}{*}{$\begin{array}{c}1 \% \\
\text { in Xylene }\end{array}$} & ++ & + & & + \\
\hline & EX10 & $\begin{array}{c}10 \% \\
\text { in ethyl alcohol }\end{array}$ & & +++ & ++ & & +++ \\
\hline & EX12 & $\begin{array}{c}12 \% \\
\text { in ethyl alcohol }\end{array}$ & & +++ & +++ & & +++ \\
\hline
\end{tabular}

*Relative evaluation

(+++ : very good, ++ : good, + : normal, - : no effect)

를 처리하지 않은 FRP 표면과 유사하였다. 자외선 차단 코 팅제(EX10, EX12)와 클리어코트, 바니시 시편 모두 유사 한 변화가 나타났으나 바니시의 경우 열화 90시간부터 표 면의 기공이 증가하는 것을 확인하였다(Table 7).

\subsection{2. 색도 및 광택도 변화}

색차 비교 결과, 총 630시간의 열화 후 미처리 FRP의 색 차는 17.5 로 가장 크게 변하였으며, 코팅제 도포 시편 중 자 외선 차단 코팅제 $\mathrm{EX} 10$ 은 색차 12.0, EX12는 10.4로 확인 되었다. 클리어코트는 색차 8.7 로 가장 낮은 변화를 보였으 며, 바니시는 색차 15.9 로 코팅제 중 가장 변색이 크게 나타 났다. 특히 자외선 차단 코팅제의 경우 색 변화가 미처리 FRP 대비 약 $1 / 2$, 클리어코트는 약 $2 / 3$ 정도 감소하였으며, 바니시의 경우 미처리 $\mathrm{FRP}$ 의 변화와 유사한 것으로 확인 되었다. 초기 색 변화가 큰 미처리 FRP와의 비교 결과, 자 외선 차단 코팅제 및 클리어코트는 감지할 수 있는 정도의 차이 $(\triangle E=1.5 \sim 3.0)$ 로 초기 변화는 크지 않은 것으로 나타 났다(Figure 1).

광택도의 경우 코팅제 도포 직후 클리어코트를 도포한 $\mathrm{FRP}$ 의 광택도가 77.7 로 가장 높았으며 바니시는 42.9로 가 장 낮았다. 열화시간에 따른 변동이 크게 나타남에 따라 열 화기간 동안의 평균값을 계산하여 열화 전, 후 비교를 실시 하였다. 열화 630시간 후 자외선 차단 코팅제 EX10은 광택 도가 5.4정도 감소하였으며, EX12는 열화에 따른 광택도 차
이는 약 1.0 으로 거의 변화 없었다. 클리어코트의 경우 열화 후 광택도가 13.6정도 감소하여 가장 크게 변하였으며, 바니 시는 열화 후 광택이 증가하는 경향을 보였다(Figure 2).

\subsection{3. 접촉각 변화}

접촉각 측정 결과, 코팅 후 모든 시편에서 미처리 FRP보 다 최소 $1.6^{\circ}$ 최대 $25.1^{\circ}$ 로 접촉각이 증가하였으며, 클리어 코트 처리 시 접촉각이 가장 높아 상대적으로 소수성을 띠 는 것을 확인하였다.

630시간 열화 후 접촉각 비교 결과, 자외선 차단 코팅제 $\mathrm{EX} 10$ 은 약 $2^{\circ}$, 클리어코트의 접촉각 변화는 $1.2^{\circ}$ 정도 증가 하여 큰 차이가 나타나지 않은 반면, EX12은 약 $8^{\circ}$ 가량 감 소하였다. 바니시는 $11^{\circ}$ 정도 감소하였는데 특히 바니시의 경우 접촉각이 지속적으로 감소하여 표면이 친수성화 되는 것으로 나타났다(Figure 3).

\subsection{4. 적외선 분광분석}

적외선 분광분석 결과, 모든 시편에서 불포화폴리에스 테르 수지를 구성하는 에스테르 작용기인 $\mathrm{C}=\mathrm{O}$ stretching (1721 cm $\left.\mathrm{cm}^{-1}\right), \mathrm{C}-\mathrm{H}$ stretching $\left(1453 \mathrm{~cm}^{-1}\right), \mathrm{C}-\mathrm{O}-\mathrm{C}$ stretching $\left(1259 \mathrm{~cm}^{-1}, 1124 \mathrm{~cm}^{-1}, 1071 \mathrm{~cm}^{-1}\right)$ 의 피크가 확인되었다. 자 외선 열화에 의한 FRP의 뚜렷한 피크 변화는 관찰되지 않 았으나 열화 후 $\mathrm{C}=\mathrm{O}$ stretching $\left(1721 \mathrm{~cm}^{-1}\right)$ 에서 흡광도가 일부 감소하였다. 열화 전 대비 열화 90 시간 진행 후 카르 
Table 7. Surface change observation of samples by degradation time $(\times 40)$

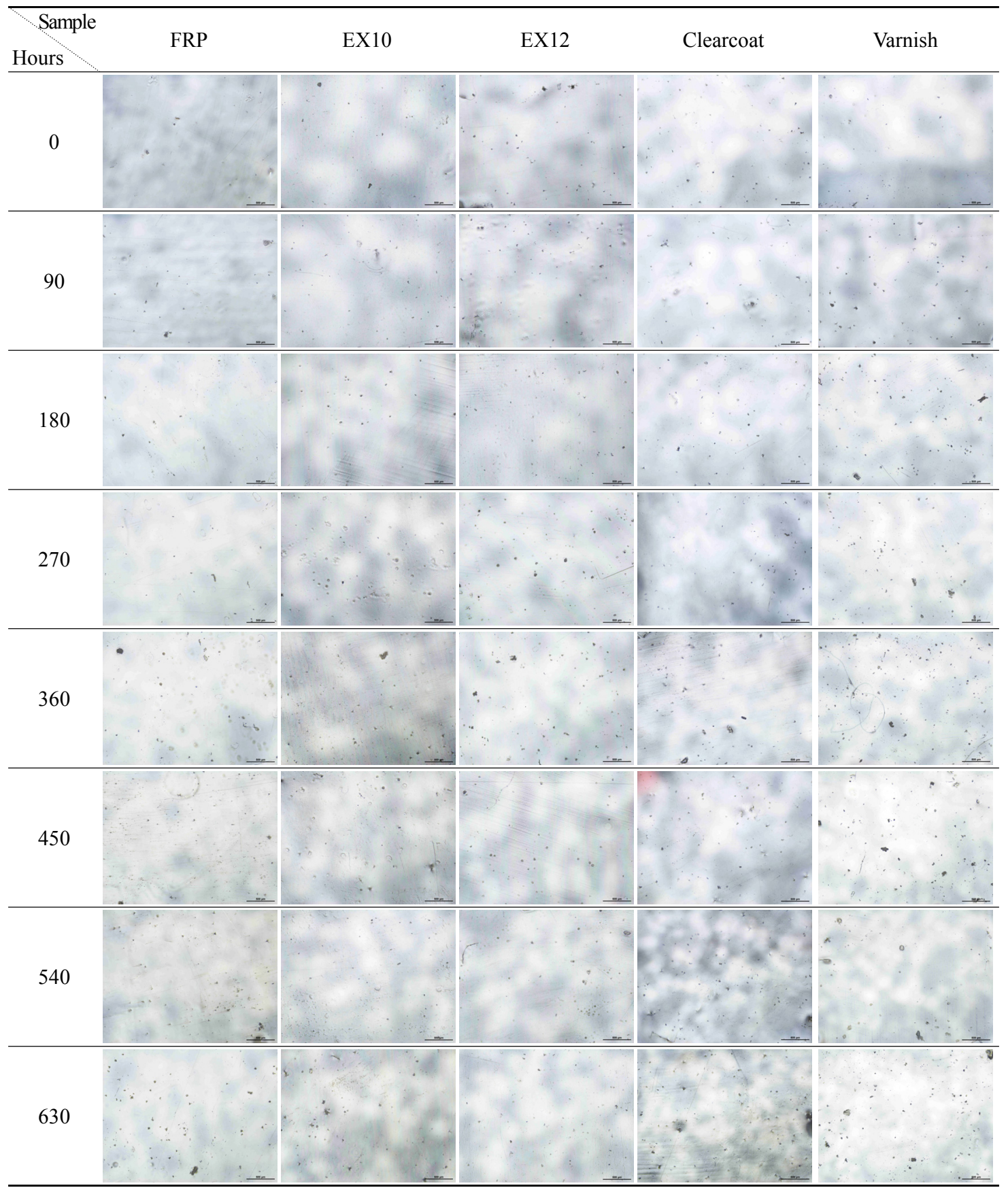

보닐 지수가 약 $15 \%$ 정도 증가하였으며 이후로는 거의 일 정한 것으로 나타났다(Figure 4).

미처리 FRP와 대조적으로 코팅제를 도포한 시편의 경
우 열화에 의한 흡광도 변화는 미미하였다. 모든 코팅제에 서 열화 전, 후 카르보닐 지수 변화가 약 \pm 1 로 나타남에 따 라 열화에 의한 확연한 차이는 관찰되지 않았다(Figure 5). 


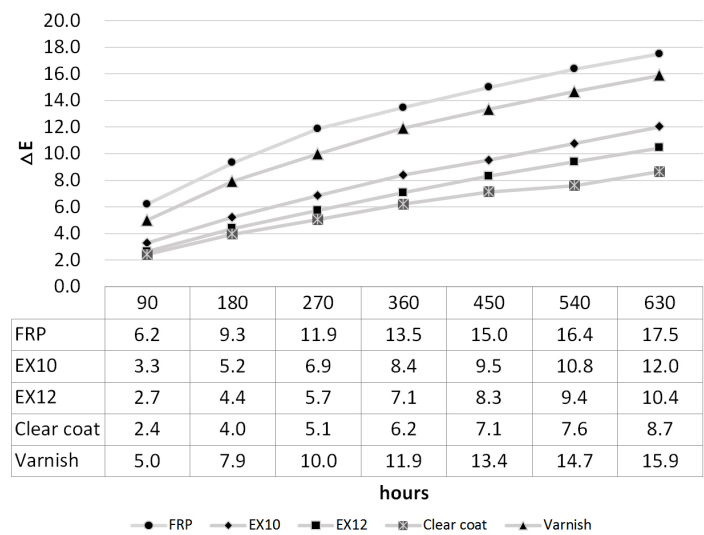

Figure 1. Color difference variation of samples by degradation time.

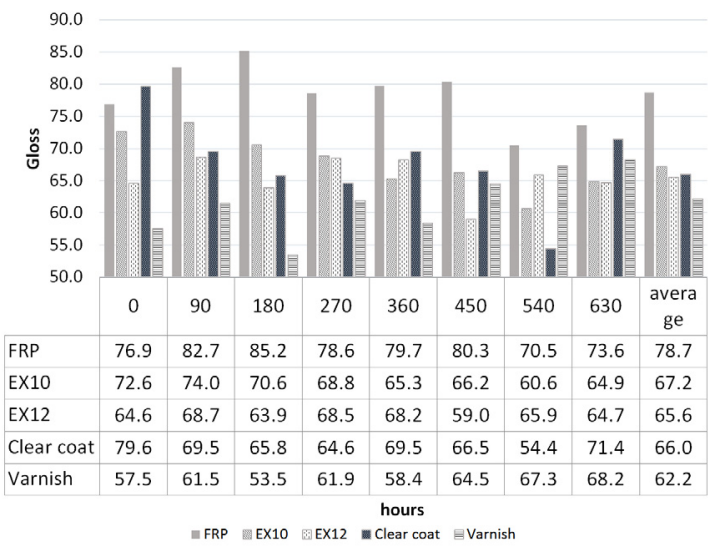

Figure 2. Gloss variation of samples by degradation time.

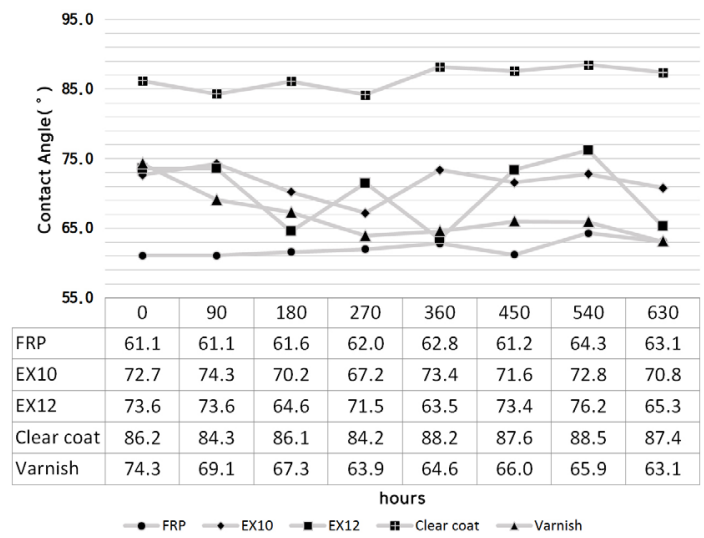

Figure 3. Contact angle variation of samples by degradation time.

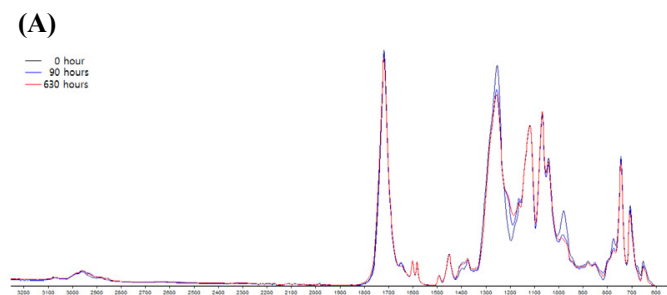

(B)

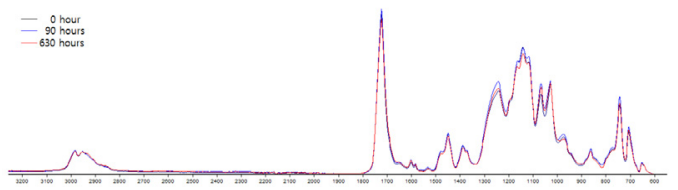

(C)

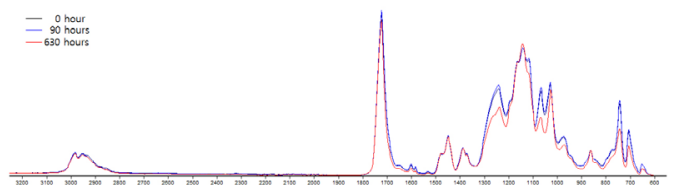

(D)

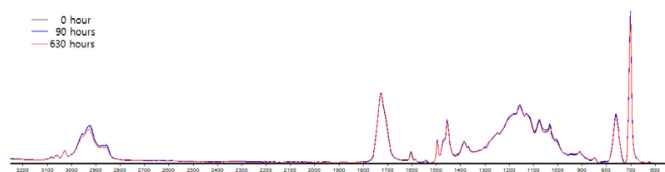

(E)

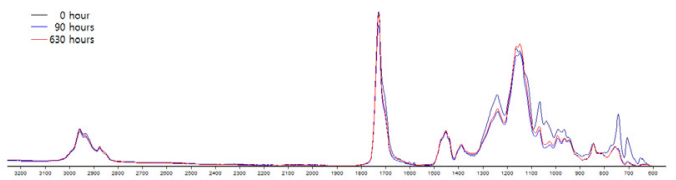

Figure 4. IR spectrum of samples by degradation time. (A) FRP, (B) FRP coated with EX10, (C) FRP coated with EX12, (D) FRP coated with clearcoat, (E) FRP coated with varnish.

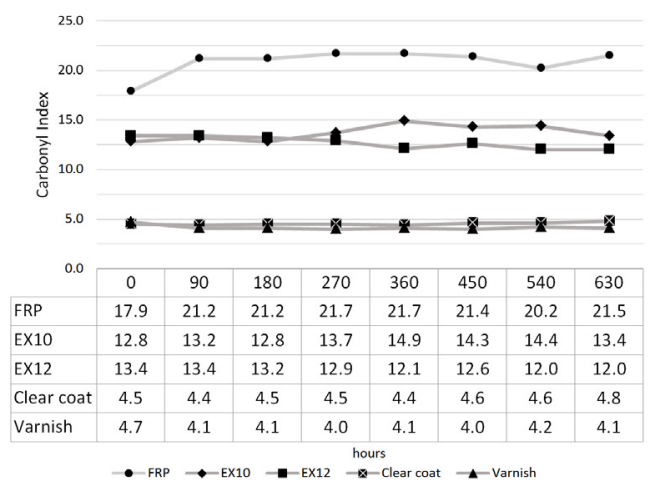

Figure 5. Carbonyl index variation of samples by degradation time. 


\section{4. 고찰 및 결론}

자외선 열화를 통해 자외선이 플라스틱에 미치는 영향 을 확인하였으며 작품의 열화를 예방하고자 코팅방법을 적 용하였다. 자외선 열화에 따른 FRP의 표면관찰 결과, 기공 이외의 다른 열화 현상은 관찰되지 않았다. 일반적으로 균열, 터짐, 백아화(Chalking) 등의 열화 현상은 기공, 균열 부위에 수분이 유입되면서 표면 또는 표면 하층에서 화학 적 변화가 발생하거나 주변의 온도 변화에 따른 기계적 응 력에 의해 나타나는 것으로 보고되나(Lee et al., 1996; Jia et al., 2010), 본 연구에서는 자외선 열화만 진행됨에 따라 수분 및 다른 요인에 의한 추가적인 열화 현상은 관찰되지 않은 것으로 판단된다. 실제 야외 환경에 노출된 $\mathrm{FRP}$ 의 경 우 자외선 뿐만 아니라 수분에 의한 영향을 받으므로 열화 양상은 더욱 다양하게 발생할 것으로 생각된다.

열화에 따른 미처리 FRP의 표면 색차 결과, 자외선 조사 90 시간 후 색차 6이상의 확연한 색 변화가 나타나 특히 열 화 초기에 변색이 빠르게 진행되는 것으로 판단된다. 광택 도는 열화 전, 후 뚜렷한 차이는 발생하지 않았으며, FRP의 열화 전 대비 열화 후 접촉각의 변화는 역시 미미하였다. 접촉각 결과로 보아 자외선 열화에 따른 표면의 물성변화 는 크지 않은 것으로 보이며, 이는 앞서 뚜렷한 변화가 나 타나지 않은 표면관찰 결과와도 일치하는 것으로 판단된 다. 적외선 분광분석 결과, $\mathrm{FRP}$ 를 구성하는 불포화폴리에 스테르 수지의 에스테르 작용기를 확인하였다. 카르보닐 지수 계산 결과, 열화 전 대비 열화 90시간 후 카르보닐 지 수가 증가하여 화학적 변화는 열화 초기에 빠르게 진행되 는 것으로 생각된다. 이는 앞서 열화 90시간 만에 색차가 크게 증가한 FRP의 색 변화 결과와 유사하여 황변을 유발 하는 것으로 알려진 카르보닐기의 변화에서 기인한 것으로 보인다(Lee and Lee, 1999; Heo et al., 2002).

이를 통해 자외선은 FRP의 물리적 변형보다 표면의 색 상 변화에 가장 큰 영향을 미치는 것으로 확인되었다. 작품 의 표면 변화, 특히 재질의 변색은 작품의 원형에 중요하게 작용하므로 작품 보존을 위해서는 색 변화가 시작되는 초 기 열화의 제어가 중요할 것으로 사료되며 고분자의 경우 한번 열화되면 되돌릴 수 없는 특성을 지니므로 열화의 예 방 및 관리가 필수적이다.

본 연구에서는 작품 표면의 열화를 예방하기 위해 자외 선 차단 코팅제를 제조하여 적용하였다. 자외선 차단 코팅 제는 농도 $10 \%, 12 \%$ 의 Paraloid B-72(in ethyl alcohol) 코
팅제에 $1 \%$ 의 자외선 안정제(in xylene)를 혼합할 때 가장 효과적임을 확인하였다.

제조한 자외선 차단 코팅제의 성능 평가를 위해 코팅제 를 도포한 FRP의 표면 관찰 결과, 코팅제 처리에 따른 변화 는 거의 나타나지 않아 미처리 FRP의 표면과 유사한 모습 이 확인되었다. 자외선 열화에 따른 색차 비교 결과, 코팅 제 도포 시 미처리 FRP보다 색 변화가 적은 것으로 나타났 다. 자외선 차단 코팅제(EX10, EX12)는 동일한 열화 시간 동안 미처리 FRP 대비 $1 / 2$, 클리어코트는 $2 / 3$ 정도 색차가 감소한 것으로 보아 FRP의 변색 제어가 가능한 것으로생 각된다. 그러나 바니시의 경우 미처리 FRP와 거의 비슷한 속도로 변색되는 것으로 보아 자외선 제어 효과는 미약하 였다. 광택도 비교 결과, 자외선 차단 코팅제는 광택도가 일부 감소하였으나 변화가 미미하여 상대적으로 열화에 안 정하였으나, 클리어코트는 열화 시간이 경과되면서 광택도 가 급격히 감소하는 것으로 보아 자외선에 취약한 것으로 생각된다. 접촉각 측정 결과, 미처리 FRP 대비 코팅제 처리 후 모든 시편에서 접촉각이 증가하였는데 이는 FRP 표면 에 코팅제가 도포됨에 따라 기존의 FRP 표면보다 상대적 으로 소수성화 된 것으로 보인다(Choi, 2008). 자외선 열화 후 자외선 차단 코팅제, 클리어코트의 경우 접촉각 변화가 크지 않은 반면 바니시는 열화가 진행될수록 접촉각이 감 소하여 미처리 FRP와 유사한 접촉각으로 나타났다. 이는 바니시를 도포한 표면이 자외선으로 인해 열화되면서 표면 의 물성이 변화한 것으로 보인다. 적외선 분광분석 결과, 코팅제 처리 후 열화에 의한 흡광도 변화는 미미하였으며, 미처리 FRP와 달리 열화 전과 열화 90시간 후 역시 차이는 나타나지 않았다. 자외선 조사에도 불구하고 카르보닐 지 수의 변화가 확인되지 않았다. 이는 여러 층으로 이루어진 고분자 막에서 표면층은 자외선 노출에 의해 손상을 받았 으나 내부의 층은 표면층에서 완전한 손상이 진행되는 동 안 고분자 막의 형태적 안정성을 유지하였다는 결과로 보 아(Lee et al., 2015), 코팅제 처리를 통해 FRP 표면에 형성 된 코팅막에서 열화가 우선적으로 진행되어 열화 시간동안 내부의 FRP 층은 비교적 안정한 상태가 유지된 것으로 추 정된다.

본 연구를 통하여 야외 플라스틱 작품에 주로 사용되고 있는 FRP를 대상으로 자외선에 의한 열화 양상을 파악하 였으며, 코팅제 처리를 통한 FRP 표면의 열화 제어 및 야외 FRP 작품의 보존방안으로써 코팅제의 적용 가능성을 확인 하였다. 특히 직접 제조한 자외선 차단 코팅제의 변색 제어 
효과를 확인하였으며, 클리어코트의 경우 작품의 표면 보 호 및 광택 부여를 위한 상도 도료로 사용할 뿐만 아니라 재처리 및 보존용 코팅제의 역할도 가능할 것으로 사료된 다. 향후 야외 환경에서 $\mathrm{FRP}$ 의 열화 양상을 평가하고 코팅 제의 현장 적용 연구가 진행된다면 야외 플라스틱 작품의 보존 관리에 활용 가능할 것으로 기대된다.

\section{REFERENCES}

Beerkens, L. and Breder, F., 2012, Temporary art? The production and conservation of outdoor sculptures in fiberglass-reinforced polyester. Conservation Perspectives The GCI Newsletter, 27(2), 13-14.

Beom, D.G., 2012, A study on application of nano-ceramic resin as a coating agent for conservating outdoor metal cultural assets. Master's thesis, Chonbuk University, Jeonju. (in Korean with English abstract)

Breder, F., 2013, Preserving artistic style and authentic appearance in hand-painted outdoor sculptures. Proceedings from the interim meeting of the Modern Materials and Contemporary Art Working Group of ICOM-CC, Otterlo, June 4-5, 65-71.

Cho, H.K. and Cho, N.C., 2008, Characterization study of various solvents of Paraloid B72 for bronze artifacts conservation by surface analysis. Journal of Conservation Science, 22, 61-76. (in Korean with English abstract)

Choi, J.K., 2008, A way to explain the concept of surface tension and intermolecular interaction by measuring the contact angle. Master's thesis, Korea National University of Education, 1. (in Korean with English abstract)

Chung, Y.J., Yu, J.A. and Kang, D.I., 2013, Preservation values and effects on cleaning and adhesive agents for plastic artifacts. Journal of Conservation Science, 29(2), 127-138. (in Korean with English abstract)

Getty Conservation Institute, 2012, Conservation Perspectives The GCI Newsletter, 27(2).

Ha, S.M., 2013, A study on material characteristics of synthetic resins used in modern sculpture. Master's thesis, Konkuk University, Chungju, 30-34. (in Korean with English abstract)

Heo, M.H., Kim, S.W., Ha, G.R., Mori, T., Hong, K.H. and Seo,
K.H., 2002, Discoloration and the effect of antioxidants on thermo-oxidative degradation of polyamide 6 . Polymer (Korea), 26(4), 452-461. (in Korean with English abstract) Jeon, J.P., Jung, S.T., Kim, H.B., Oh, S.H. and Kang, P.H., 2013, The effect of electron beam irradiation on discoloration and thermal property of HDPE filled with antioxidants and UV stabilizer. Journal of Radiation Industry, 7(1), 23-28. (in Korean with English abstract)

Jia, Z., Li, X. and Zhao, Q., 2010, Effect of artificial weathering on surface properties of unsaturated polyester(UP) resin. Materials Chemistry and Physics, 121, 193-197.

Korea Meteorological Administration, 2016, UV-A intensity in Anmyeondo(2012-2014). http://data.kma.go.kr/

Lee, D.C., Park, K.S., Hwang, M.W. and Tabate, Y., 1996, A study on the aging properties of FRP insulation materials by ultraviolet and ozone gas. The Transaction of the Korean Institute of Electrical Engineers, 45(12), 1996. (in Korean with English abstract)

Lee, B.S. and Lee, D.C., 1999, A study on the surface degradation properties of epoxy/glass fiber treated with ultraviolet rays. The Transaction of the Korean Institute of Electrical Engineers, 48(2), 86-91. (in Korean with English abstract)

Lee, G.R., 2006, A study on the characteristics of materials used in Korean environmental sculptures. Master's thesis, Suwon University, Hwaseong, 34-35. (in Korean with English abstract)

Lee, J.H., Kim, S.B. and Cho, K.Y., 2015, A study on the effect of accelerated UV exposure on the polymer membrane for outdoor users. Applied Chemistry for Engineering, 26(3), 326-330. (in Korean with English abstract)

Mun, M.J., 2003, Synthesis and characterization of UV curable light stabilizer containing acrylate group. Master's thesis, Chosun University, Gwangju, 2-7. (in Korean with English abstract)

Nam, K.T.. Hong, C.K., Chae, K.H. and Kaang, S.Y., 2006, A study on UV degradation of SBR and NR containing polymeric UV stabilizer. Elastomers and Composites, 41(3), 182-193. (in Korean with English abstract)

Oh, H.H., 2012, A study on the stability of EVA coating materials on metal relics. Master's thesis, Hanseo University, 
Seosan, 19. (in Korean with English abstract)

Oh, S.J., 2010, A study on property changes matter of metal coating materials by air pollution. Master's thesis, Hanseo University, Seosan. (in Korean with English abstract)

Park, H.J., 2006, Study on the effect of interception and physical special quality of sculpture and cultural assects in the outdoor environment. Master's thesis, Hanseo University, Seosan. (in Korean with English abstract)

Park, H.J., 2016, A case study on the conservation of outdoor sculpture in Korea. Master's thesis, Konkuk University, Chungju 4-6. (in Korean with English abstract)
Shin, J.H., 2005, The study of jewelry design using the resin -Centering on unsaturated polyester resin and epoxy resin-. Master's thesis, Hanyang University, Seoul. (in Korean with English abstract)

Youn, J.Y., Kim, S.W., Park, B.H., Lee, S.H., Kwon, T.H. and Kim, K.T., 2011, A study on structure analysis system for short fiber reinforced plastics. Composites Research, 24(4), 41-47. (in Korean with English abstract)

Yu, J.A., 2013, Study on identification and conservation of plastic artifacts. Master's thesis, Chung-ang University, Seoul. (in Korean with English abstract) 